\title{
Az ONLINE OKTATÁS FEJLŐDÉSE ÉSZAK-AMERIKÁbAN
}

\author{
DEÁK DOROTTYA
}

ELTE Szociológia Doktori Iskola

Beérkezett: 2021. január 25., elfogadva: 2021. február 5.

Edward C. Hamilton: Technology and the Politics of University Reform: The Social Shaping of Online Education. Houndmills Basingstoke Hampshire, New York, 2016. Palgrave Macmillan. xxii + 237 p. ISBN: 978113750350 (eBook)

A technológia fejlődésével előtérbe került az oktatás modernizációja is a technológiai vívmányok oktatásba való beépítésével. Edward C. Hamilton, a Palgrave Macmillan kiadó Digital Education and Learning könyvsorozatának részeként megjelent Technology and the Politics of University Reform: The Social Shaping of Online Education címü kötete az északamerikai egyetemek online oktatási rendszerre való törekvéseit ismerteti. $\mathrm{Az}$ online oktatás reformerei különböző fejlődési utakat kerestek a technológiai eszközök felhasználási lehetőségei során. Az olvasmány nem az oktatási rendszer egészének fejlődését, történetét mutatja be, a fejezetekben említett minden egyes példa egy adott innovációra vagy innovációs típusra összpontosít.

Hamilton egyik fó hipotézise, hogy miközben az infokommunikációs eszközök életünk és mindennapjaink részévé váltak, integrálásuk a formális oktatásba marginális maradt. (Az egyetemi működésnek a Covid-19-vírus által kikényszerített digitális oktatásra való átállása előtt ez a megállapítás helytálló is volt.)

A könyv elsősorban az Egyesült Államokra és Kanadára összpontosít (helyenként kitekintéssel az Egyesült Királyságra), és a két ország felsőoktatásának a 20. század végén és a 21. század első évtizedében történő változásait mutatja be egyegy példán keresztül. Hamilton rávilágít arra, hogy az online oktatás nem homogén jelenség, különböző fejlődési utak mentén jött létre (ezeket a 3-7. fejezetben részletezi). A kötet nem vázolja fel az adott időszakban zajló fejlődések teljes skáláját, hanem olyan kiemelkedő eseményekre mutat rá, amelyek az online oktatás viszonylatában jelentősnek tünnek az egyetemi reform politikája szempontjából. Hamilton szerint nem a technológia fejlődése hatott önmagában az oktatásra, az oktatás technológiai változásai inkább társadalmi és környezeti szempontokat tükröznek. Az első két fejezet egy összefoglaló, amely az online oktatás fejlődése elemzésének elméleti alapjait ismerteti.

$\mathrm{A} z$ első fejezet (Online education and the politics of technology) a technika oktatásba való konvertálásának két eltérő megközelítését hasonlítja össze. Az online oktatás hívei többféle módon, a technika fejlődésének és oktatásba való integrálásának pozitív oldalát tekintették mérvadónak, és elsősorban költséghatékonysági szempontokat vettek figyelembe. Az oktatás reformjának kritikusai attól tartottak, hogy az oktatás online térbe való áthelyezésével és a számítógépek, ok- 
tatói portálok bevezetésével a hagyományos oktatási értékek elvesznek (olcsóbb és gyengébb képességű tanárokat lehet alkalmazni). Az eltérő vélemények ellenére mindkét fél a gazdasági ésszerűséget és az oktatás jövőjét (pozitív vagy negatív értelemben) látta az online oktatásban. Hamilton a vita feloldására a fejezetben olyan példákat mutat be, melyek a technikai fejlesztések oktatásban való használata során igyekeznek a hagyományos oktatás értékeit magukba építeni, nem pedig figyelmen kívül hagyni.

A második fejezetben (From constructivism to normative critique: Technology, history, and politics) az író elsősorban Feenberg kritikai technológiaelméletét veszi alapul. Az elméletet és az első fejezetben felvázolt vitát követve Hamilton azt az érvet vezeti végig e fejezetben, példákkal illusztrálva, hogy a technológia és az online oktatás nem értelmezhetők a társadalmi kontextusok, az oktatás társadalomban betöltött szerepe nélkül. A további fejezetek azokra az érdekekre és logikákra fókuszálnak, melyek az online oktatás fejlődését alakították: automatizálás, ambivalencia, evangelizáció, nyitottság.

A harmadik fejezet (The age of automation: The technical code of online education to 1980) a számítógép által vezérelt oktatás (CAI - computer-assisted instruction) kezdeti fejlődését ismerteti. A CAI-rendszerek a tömegesítés logikájára jöttek létre. Céljuk, hogy minél több felhasználó vegyen részt a tanulásban egy időben, ezzel költséghatékonyabbá téve az oktatást. Hamilton összefüggéseket von le a CAI-rendszerek használata és a távoktatás tapasztalatai között. Az ilyen típusú számítógép által vezérelt oktatás során szükségessé vált az oktató és a tanuló, vagyis a tanítás és a tanulás szétválasztása. Ehhez hasonlóan a tanulók is elkülönültek egymástól, továbbnövelve a tanulás individualizálását. Újra kellett értelmezni az oktatók szerepét és a visszacsatolási lehetőségeket. A CAI elérte kitűzött célját: előre összeállított információcsomagokat adott át szélesebb körben, automatizálta az oktatás folyamatát, támogatta az egyéni fejlődést, gépesítette az oktató számos funkcióját a tanulás során, de megtartotta az oktatás feletti ellenőrzés lehetőségét az oktatási intézmények számára. A CAI-rendszerek sikere ellenére számos kritikus jelezte problémáját vele és a hozzá hasonló típusú, iparosított és automatizált oktatással kapcsolatban. Az 1980-as évek elején számos kísérlet kezdődött olyan, számítógéppel közvetített oktatási formák létrehozására, amelyek gyökeresen ellentétesek a CAI logikájával. $\mathrm{A} z$ így létrehozott számítógépes oktatási célú konferenciarendszerek a társadalmi interakciót vették alapul, és a számítógép által nyújtott kommunikációs lehetőségeket használták fel az oktatás során.

A negyedik fejezet (The age of ambivalence: Early experiments in educational computer conferencing) ezeknek az online konferenciarendszereknek a lehetőségeit mutatja be összehasonlítva a CAI-típusú oktatás működésével. Annak ellenére, hogy előbbieknek az interakció, az egyének és csoportok közötti kommunikáció volt a fö mozgatórugója, Hamilton szerint a technológia oktatásba való bevezetésével - a CAI oktatási módhoz hasonlóan - az egyetemek és felsőoktatási intézmények elsődleges célja továbbra is a költséghatékonyság, a minél nagyobb számú hallgató elérése, az oktatás árucikké alakítása és kereskedelmi forgalomba hozatala volt.

$\mathrm{A} z$ ötödik fejezet (The age of evangelism: From online education to the virtual university) a politikai és gazdasági változások mentén azt vizsgálja, hogy a felsőoktatási intézmények miként értelmezték újra az online oktatás lehetőségét, létrehozva a virtuális egye- 
tem fogalmát. A fejezet az egyetemek, a technológia és az oktatói gárda oldaláról tanulmányozza a változásokat. $\mathrm{A} z$ új gazdasági igények miatt sokan megkérdőjelezték az egyetemi oktatás tartalmát, minőségét és akkori gyakorlatát. Gazdaságilag hatékonyabbnak tünt egy CAIrendszerhez hasonló, nagy adatbázissal rendelkezdő, automatizált online oktatási forma kialakítása. Az online oktatásban rejlő lehetőségek kiaknázása a tanítás minőségének javítása, az oktatókhallgatók arányának optimalizálása és a pedagógiai módszerek fejlesztése helyett a termelékenység és a hatékonyság növelésére összpontosult.

A 2000-es évek elejére az online oktatás az egyik legvitatottabb jelenséggé vált az egyetemek működésében. A hatodik fejezetben (The age of openness: From critical interventions to the encoding of online education) ismertetett fejlődési szakaszban az online oktatás az egyetemeken a "nyitottság” alapelve mentén alakult át. Hamilton a fejlődés e periodizációjában három olyan fejlesztési területet említ, amelyek együttesen alakították át az online oktatás későbbi működését. Elsőként az egyetemek újragondolták az online oktatás kereteit, bevonva az egyetemek oktatóit is, hogy az online oktatás ne csak a gazdaság igényeit szolgálja, mint korábban, hanem a hagyományos tudományos értékeket is képviselje. A második fejlődési terület a kevert vagy vegyes tanulási módszer megjelenése volt. A vegyes tanulás ötvözte a hagyományos, személyes oktatást az online, számítógépes oktatással. Ez a megoldás előnyösebbnek tünt, mint a korábbi távoktatás vagy a hagyományos oktatás számítógépes automatizálása. A fejlődési folyamat végül a nyílt forráskódú és nyílt hozzáférésű tanítás bevezetéséhez vezetett. A cél az volt, hogy az online oktatás nyújtotta új lehetőségeket korábbról megszokott hagyományos egyetemi szakmai értékekkel és gyakorlatokkal egészítsék ki.

A hetedik fejezet (The ambivalence of openness: MOOCs and the critical practice of online education) a $\mathrm{ma}$ is használatos tömeges nyílt online tanfolyamok (MOOC - massive open online courses) kialakulását követi végig. A MOOC-ok olyan kurzusok, melyek korlátlan beiratkozást tesznek lehetővé, és (többnyire) ingyenesen elérhetők mindenki számára. A MOOC-ok igyekeznek a tömegesítésből és az oktatás piacosításából fakadó hátrányokat csökkenteni a korábbi fejezetben felvetett nyitottság paradigmájával. A nyílt hozzáférésű online tanfolyamok hatékony müködése rávilágít arra a tényre, ami a korábbi fejezetekből is kiderül, hogy az online oktatással nem szükségszerű a hagyományos egyetemek teljes átalakulása és megszünése. Az előző fejezetekben bemutatott fejlődési folyamatok és az ebben a fejezetben említett kétfajta MOOC (cMOOC és xMOOC) rámutatnak arra, hogy az online oktatásnak még mindig nincs egy kiforrott, mindenki által elfogadott módja. A politikai szereplők, egyetemek, oktatók, kutatók és hallgatók előtt még számos módszertani lehetőség áll, a technológia folyamatos fejlődése miatt ráadásul a paletta további bővülése várható.

A könyv az online oktatás északamerikai fejlődési útjait követi végig az egyetemek gazdasági érdekei, az oktatók szerepének átalakulása és a hallgatók tanulásának önállósítása mentén. Hamilton ezt maga is megemlíti, hozzátéve, hogy a következtetések alkalmazhatósága megkérdőjelezhető más társadalmi összefüggésekben (eltérő oktatási hagyományok, oktatási jogszabályok, technikai infrastruktúra; különböző fejlettségi szintek, helyi és egyéni kultúrák, gyarmatosító országok hatása a gyarmatok felsőoktatására stb.). A könyvvel Hamiltonnak 
nem volt célja egy stabil terminológia kialakítása, csupán az oktatási koncepciók és a technológia megtervezése, fejlesztése és megvalósítása közötti összefüggéseket kívánta feltárni, ezzel - reményei szerint - párbeszédre hívva más kutatókat is a téma nemzetközi megvitatására.

A cikk a Creative Commons Attribution 4.0 International License (https://creativecommons.org/licenses/ by-nc/4.0/) feltételei szerint publikált Open Access közlemény, melynek szellemében a cikk bármilyen médiumban szabadon felhasználható, megosztható és újraközölhető, feltéve, hogy az eredeti szerző és a közlés helye, illetve a CC License linkje és az esetlegesen végrehajtott módosítások feltüntetésre kerülnek. 